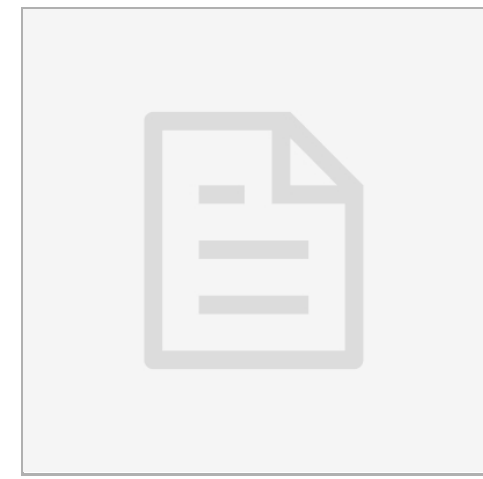

FEB 10, 2021

\section{open ठAccess}

DOI:

dx.doi.org/10.17504/protocol s.io.bkguktww

\section{Protocol Citation: Eric RA} Pederson 2021. Serapure Bead production . protocols.io

https://dx.doi.org/10.17504/p rotocols.io.bkguktww

License: This is an open access protocol distributed under the terms of the Creative Commons Attribution License, which permits unrestricted use, distribution, and reproduction in any medium, provided the original author and source are credited

Protocol status: Working We use this protocol and it's working

Created: Aug 29, 2020

Last Modified: Feb 10, 2021

PROTOCOL integer ID: 41204

Keywords: speed beads

\section{(3) Serapure Bead production}

Eric RA Pederson ${ }^{1}$

${ }^{1}$ Uppsala University

methods

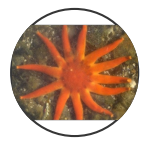

Eric RA Pederson

Uppsala University

\section{ABSTRACT}

Production of DNA size separation magnetic beads.

\section{MATERIALS}

\section{MATERIALS}

88 Sera-Mag Speed Beads GE Healthcare Catalog \#65152105050250

88 PEG 8000 Merck MilliporeSigma (Sigma-Aldrich) Catalog \#81268

\section{SAFETY WARNINGS}

(1) Wear gloves.

\section{BEFORE START INSTRUCTIONS}

Just make sure all the components have been purchased. It is not a difficult protocol

\title{
Serapure bead production
}


1 In a $50 \mathrm{~mL}$ conical using sterile stock solutions, prepare TE (10 mM Tris-- $\mathrm{HCl}$ and $1 \mathrm{mM}$ EDTA); - $500 \mu \mathrm{L} 1 \mathrm{M}$ Tris pH8

- $100 \mu \mathrm{L} 0.5 \mathrm{M}$ EDTA

Fill conical to $50 \mathrm{~mL}$ mark with $\mathrm{dH} 20$.

2 To a to a new $50 \mathrm{~mL}$, sterile conical add;

- 9 g PEG--8000

$-10 \mathrm{~mL} 5 \mathrm{M} \mathrm{NaCL}$ (or $2.92 \mathrm{~g}$ )

- $500 \mu \mathrm{L} 1 \mathrm{M}$ Tris--HCL

- $100 \mu \mathrm{L} 0.5 \mathrm{M}$ EDTA

- 0.250 ul $10 \%$ tween-20

- Fill to $49 \mathrm{~mL}$ using sterile $\mathrm{dH} 20$.

Mix conical for about 3--5 minutes until PEG goes into solution (solution, upon sitting, should be clear).

-Fill to $\sim 49 \mathrm{~mL}$ using sterile $\mathrm{dH} 20$. gently.

3 Mix Sera--mag SpeedBeads and transfer $1 \mathrm{~mL}$ to a $1.5 \mathrm{~mL}$ microtube.

\section{Sera-Mag Speed Beads GE Healthcare Catalog \#65152105050250}

$4 \quad$ Place SpeedBeads on magnet stand until beads are drawn to magnet. Discard supernatant

5 Add $1 \mathrm{~mL}$ TE to beads, remove from magnet, mix, return to magnet. Discard supernatant

6 Add $1 \mathrm{~mL}$ TE to beads, remove from magnet, mix, return to magnet. Discard supernatant

$7 \quad$ Add $1 \mathrm{~mL}$ TE to beads and remove from magnet. Fully resuspend and set microtube in rack (i.e. not on magnet stand). 
$8 \quad$ Mix $1 \mathrm{~mL}$ SpeedBead + TE solution and transfer to $50 \mathrm{~mL}$ conical.

9 Fill conical to $50 \mathrm{~mL}$ mark with $\mathrm{dH} 20$ (if not already there) and gently mix $50 \mathrm{~mL}$ conical until brown.

10 Wrap in tinfoil (or place in dark container) and store at $4^{\circ} \mathrm{C}$.

11 Test against AMPure XP using aliquots of ladder (Fermentas GeneRuler).I recommend the $50 \mathrm{bp}$ ladder in place of the ultra--low rangeladder.

12 Mix $2 \mu \mathrm{LGeneRuler} \mathrm{with} 18 \mu \mathrm{L} \mathrm{dH} 20$.

13 Add $20 \mu \mathrm{LGeneRuler} \mathrm{mixture} \mathrm{to} \mathrm{a} \mathrm{volume} \mathrm{of} \mathrm{Serapure} \mathrm{and/or} \mathrm{AMPure(the} \mathrm{specific} \mathrm{volume}$ depends on whether you are trying exclude small fragments or not; see the figure on the next page).

13.1 Use 20ul of the ladder/water mix and add to these amounts of the serapure beads and the ampure beads.

$0.9 \mathrm{X}$ sample - $18 \mathrm{ul}$

$1.2 X$ sample- 24 ul

$1.5 \mathrm{X}$ sample - $30 \mathrm{ul}$

$1.8 \mathrm{X}$ sample- 36 ul

2.1X sample - 42 ul

$2.5 \mathrm{X}$ sample - $50 \mathrm{ul}$

$2.7 X$ sample - $54 \mathrm{ul}$

14 Incubate mixture 5 min.at room temperature. 
15 Place on magnet stand.

Discard supernatant.

16 Add $500 \mu \mathrm{L} 70 \%$ EtOH.

17 Incubate on stand for $1 \mathrm{~min}$.

Discard supernatant.

18 Add $500 \mu \mathrm{L} 70 \%$ EtOH.

19 Incubate on stand for $1 \mathrm{~min}$.

Remove supernatant.

20 Place beads on $37^{\circ} \mathrm{C}$ heat block for 3--4 min.until dry.

21 Re-hydrate with $20 \mu \mathrm{LdH} 20$ for 5 minutes.

22 Place on magnet stand.

Transfer supernatant to new tube. 
23 Mix supernatant with $3 \mu$ Lloading dye.

Use the same ladder

Electrophorese in $1.5 \%$ agarose for 60 minutes at $100 \mathrm{~V}$ (or as you please) 